\title{
IN VITRO ANTI-INFLAMMATORY ACTIVITY OF BLUE-GREEN ALGAE-GEITLERINEMA SPLENDIDUM COLLECTED FROM WESTERN GHATS, SOUTH INDIA
}

\author{
KRISHNAVENI J, ALARMAL MANGAI S*, MARY JENCY I \\ Department of Chemistry, Karpagam College of Engineering, Coimbatore, Tamil Nadu, India. Email: mangai24phyto@gmail.com
}

Received: 15 February 2017, Revised and Accepted: 26 March 2018

ABSTRACT

Objective: Geitlerinema splendidum is non-edible blue-green algae available in freshwater systems. It belongs to Pseudanabaenacae genera. In exploring the medicinal properties of algae, our present work aimed to analyze the anti-inflammatory effect of the algae G. Splendidum.

Methods: Anti-inflammatory activity was carried out by human red blood cell membrane stabilization assay for ethyl acetate and ethanol crude extracts of alga and found that the ethyl acetate extract has better inhibitory property than ethanol crude extract. Diclofenac was used as the standard drug.

Results: The experimental results obtained are comparable to the reference drug and are found to be dose-dependent. Even at a minimum concentration of $12.5 \mu \mathrm{g} / \mathrm{ml}$, the percentage inhibition was in the range of $56.6 \pm 0.12-58.5 \pm 0.03 \%$, which indicated that the alga $G$. splendidum has a satisfactory anti-inflammatory activity.

Conclusion: Our present work is supposed to be the first report in exploring the anti-inflammatory effect of the algae G. splendidum.

Keywords: Anti-inflammatory effect, Blue-green algae, Diclofenac, Geitlerinema splendidum, Human red blood cell.

(C) 2018 The Authors. Published by Innovare Academic Sciences Pvt Ltd. This is an open access article under the CC BY license (http://creativecommons. org/licenses/by/4. 0/) DOI: http://dx.doi.org/10.22159/ajpcr.2018.v11i5.25301

\section{INTRODUCTION}

Inflammation is a local response of living tissue of our body when injured [1] which involves a multiple arrays of processes such as enzyme activation, cell migration, tissue breakdown, and repair [2]. Inflammation can either acute or chronic. Acute inflammation is the initial response of the body to harmful stimuli [3]. Chronic inflammation can lead to a number of diseases such as hay fever, periodontitis, rheumatoid arthritis, atherosclerosis, and gallbladder carcinoma [4]. Hence, the chronic inflammatory disease is one of the major health issues challenging the medicinal field. The inflammation is the first stage of any discomforts in the biological system of the human body. Nowadays, the usage of synthetic drugs is dominating the medicinal market in the treating inflammatory diseases. In particular, the nonsteroidal anti-inflammatory drugs (NSAIDs) are notable widespread classes of medicine globally for inflammation and other related diseases. These drugs are carboxylic acid-based compounds which reduce the enzyme activity and block the cyclooxygenase pathway $[5,6]$. However,the predominant side effects such as peptic ulcer, perforation, and bleeding associated with these drugs $[7,8]$ make the urge of searching complementary medicine with safe efficacy. The natural products are believed as one of the reliable sources in the medicinal field [9]. In this regard, we focused our research work on the medicinal properties of blue-green algae (BGA).

Cyanobacteria, commonly known as BGA, are available worldwide in diverse habitats. Algae are members of aquatic organisms belonging to the Protista kingdom which are in different shapes and sizes. Their physical appearances may vary with respect to sea water/saltwater and freshwater systems where they are available. They can be single cellular or multi-cellular.

The single-celled BGA are usually available in freshwater only. BGA are about $70 \%$ protein content and edible. BGA as rich in nutrients act as an energy booster [10]. Studies indicated that edible BGA have a number of medicinal properties such as antiviral, antioxidant, anti-diabetic, and anti-bacterial properties [11]. One of the edible constituent of
BGA -spiralling platensis has found to possess notable anti-cancer activity [12-15]. According to Skulberg et al. [16], there are 2000 cyanobacteria species comprising 150 generics and 40 species are toxic and non edible. However, there is no strong evidence for animal and people being intoxicated by the ingestion of cyanobacteria [17]. Based on the above-mentioned literature survey, one of the non-edible algae, Geitlerinema Splendidum was chosen for the present study.

Our research work has been extended in identifying the medicinal properties specifically the anti-inflammatory effect of the non-edible blue-green algae - G. splendidum by in vitro mode. G. splendidum is belonging to Pseudanabaenacae genera. It has a specific locality of the fresh water system and does not bloom. It has been found that $G$. splendidum has a potential inhibitory effect on acetylcholinesterase activity [18].

\section{METHODS}

\section{Collection of the tested alga}

The alga a $G$. splendidum, is collected in the freshwater system nearby the agricultural land that is situated in Coimbatore, the Western Ghats region of South India. The collected alga was authenticated by Botanical Survey of India, Coimbatore, India, and voucher specimen was kept in the Chemistry Department of the host institution with the specimen no: $17 \mathrm{CH} 216$. The alga was shadow dried for $40 \mathrm{~d}$. Then, it is powdered in the laboratory pulverizer. The powdered biomass is sieved using 250 mesh wire sieve and stored in an airtight container which is used for further experiments.

\section{Alga description}

G. splendidum is a Colony (thallus) spreading with bundles of filaments. They are in bright green to blue-green color. Trichomes are up to $1 \mathrm{~mm}$ long, little bent and entangled. Cells are 2-4 times longer than wide. The salient diacritic feature is the morphology of trichomes without sheaths [19]. The morphological description G. splendidum has not yet been clearly published, although the images and phylogeny were documented in Hasler et al. [20]. 
Preparation of crude extracts

The crude extracts were prepared by cold percolation process. An approximately weighed $1 \mathrm{~kg}$ of the alga was defatted with petroleum ether for about $4 \mathrm{~h}$. The solvent was carefully removed by rotary evaporator. Then, the algae powder was macerated with ethyl acetate and ethanol sequentially. The crude extracts were obtained after removing the solvents using rotary evaporator and were stored in airtight container.

Anti-inflammatory study by human red blood cell (HRBC) membrane stabilization method

HRBC method was used to determine the anti-inflammatory activity of the algae as described in the literature [21,22]. The blood sample was collected from healthy volunteer who was not taking any nonsteroidal drugs two weeks before the experiment. The blood was mixed with equal volume of sterilized Alsever solution ( $2 \%$ dextrose, $0.8 \%$ sodium citrate, $0.05 \%$ citric acid, and $0.42 \% \mathrm{NaCl}$ in water). After centrifuging the reaction mixture at a rate of $3,000 \mathrm{rpm}$, the packed cells were isolated, and $10 \% \mathrm{v} / \mathrm{v}$ suspension was made with isosaline. The HRBC suspension was used for the estimation of anti-inflammatory property. Standard drug Diclofenac was used as the reference.

Different concentrations of the two extracts, reference sample, and control were separately mixed with $1 \mathrm{ml}$ of phosphate buffer, $2 \mathrm{ml}$ of hyposaline and $0.5 \mathrm{ml}$ of HRBC solution. All the assay mixtures were kept in incubation for a period of $30 \mathrm{~min}$ at $37^{\circ} \mathrm{C}$ and then centrifuged at $3000 \mathrm{rpm}$. This supernatant liquid was decanted, and the hemoglobin content was estimated by a spectrophotometer at $560 \mathrm{~nm}$. The percentage of hemolysis was estimated by assuming the hemolysis produced in the control as $100 \%$.

Percentage of Protection=100-(OD $\left.{ }_{\text {sample }}-O D_{\text {control }}\right) \times 100$

\section{Statistical analysis}

Triplicate of analysis was carried out for all concentrations to obtain the maximum accuracy. The values are statistically analyzed by oneway analysis of variance.

\section{RESULTS AND DISCUSSION}

Preparation of crude extract

The crude extracts of the algae were prepared, and the yields were found to be $6.3 \mathrm{~g}$ and $6.5 \mathrm{~g}$ of ethyl acetate and ethanol, respectively.

\section{Anti-inflammatory effect}

In vitro anti-inflammatory effect of the extracts was analyzed by HRBC membrane stabilization method. The inflammation is the reaction of living tissue to injury, infection or irritation. Lysosomal enzymes released during the inflammation produce a variety of disorders. The stabilization of this lysosomal membrane is important in limiting the inflammatory response. The NSAIDs exert their healing property, either by inhibiting the release of lysosomal enzymes or by stabilizing the lysosomal membranes [23].

Since HRBC membrane is analogous to lysosomal membrane components, the prevention of hypotonicity-induced HRBC membrane lyses can be taken as an in vitro measure of anti-inflammatory activity of Natural products [21]. The experimental data were statistically significant $(\mathrm{p}<0.02)$

The percentage of membrane stabilization for ethyl acetate and ethanol extracts of G. splendidum and Diclofenac was done at 12.5, 25, 50, and $100 \mu \mathrm{g} / \mathrm{ml}$. Both the extracts are found to be effective in inhibiting the heat produced by hemolysis of HRBC at the measured concentrations ranging from 12.5 to $100 \mu \mathrm{g} / \mathrm{ml}$. The results of the HRBC assay of the plant $G$. splendidum extracts were given in Table 1 . It was found that maximum inhibition was $71.5 \pm 0.07 \%$ at a concentration of $100 \mu \mathrm{g} / \mathrm{ml}$ for ethanol extract of alga.

With the increase in concentration, the membrane hemolysis decreases, which imply the increase of stabilization of HRBC membrane. Hence,
Table 1: Percentage inhibition of the extracts of $G$. splendidum

\begin{tabular}{|c|c|c|c|}
\hline \multirow{2}{*}{$\begin{array}{l}\text { Concentration } \\
(\mu \mathrm{g} / \mathrm{ml})\end{array}$} & \multicolumn{3}{|l|}{$\%$ inhibition } \\
\hline & $\begin{array}{l}\text { Standard } \\
\text { (Diclofenac) }\end{array}$ & $\begin{array}{l}\text { Ethyl } \\
\text { acetate } \\
\text { extract }\end{array}$ & $\begin{array}{l}\text { Ethanol } \\
\text { extract }\end{array}$ \\
\hline 12.5 & $71.5 \pm 0.08$ & $56.6 \pm 0.12$ & $58.5 \pm 0.03$ \\
\hline 25 & $78.6 \pm 0.02$ & $61.6 \pm 0.32$ & $64.6 \pm 0.05$ \\
\hline 50 & $88.6 \pm 0.05$ & $64.6 \pm 0.04$ & $68.9 \pm 0.34$ \\
\hline 100 & $93.6 \pm 0.06$ & $68.4 \pm 0.06$ & $71.5 \pm 0.07$ \\
\hline
\end{tabular}

G. splendidum: Geitlerinema splendidum

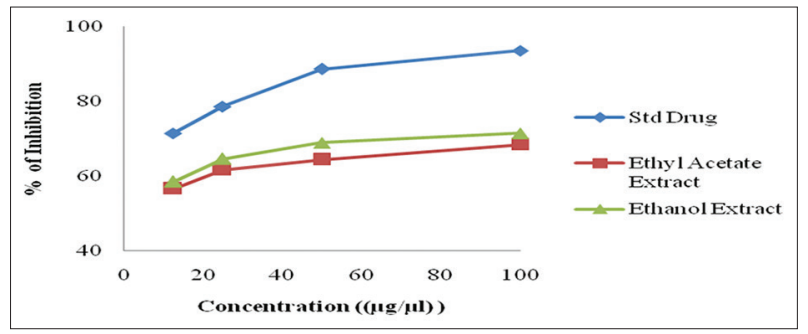

Fig. 1: Percentage inhibition versus concentrations of the extracts

the anti-inflammatory effects of the extracts are dose-dependent. Even at a minimum concentration of $12.5 \mu \mathrm{g} / \mathrm{ml}$, the percentage inhibition was in the range of $56.6 \pm 0.12-58.5 \pm 0.03 \%$ for the two extracts which indicated that the alga $G$. splendidum has a significant anti-inflammatory activity and was comparable to the standard drug Diclofenac. The graph was plotted between the concentration of extracts and the percentage of inhibition for both the extracts and was shown in Fig. 1.

\section{CONCLUSION}

The experimental results demonstrated that the extracts of alga G. splendidum at various concentrations have a significant antiinflammatory property. The results are dose-dependent with respect to the reference drug diclofenac. Hence, the tested alga G. splendidum can be an alternative biosource for anti-inflammatory agents. The antiinflammatory effect of G. splendidum has not been previously reported, and our present work is supposed to be the first report providing a scientific support to the satisfactory healing property of the tested alga $G$. splendidum in the inflammatory diseases. However, the further clinical studies to elucidate the exact inhibitory mechanism and the identification of the active constituents responsible for inhibition are likely to be studied which are our future work.

\section{CONFLICTS OF INTEREST}

The authors have no conflicts of interest.

\section{AUTHOR'S CONTRIBUTION}

The first and third authors have identified the problem, analyzed literature data and carried out the experimental part. The second has compiled the entire work.

\section{REFERENCES}

1. Joel AH, Lee EL, Alfred G. Pharmacological Basis of Therapeutics. $10^{\text {th }}$ ed. New. York: McGraw-Hill, Medical Publishing Division; 1998. p. 1465.

2. Vane JR, Botting RM. New insights into the mode of action of antiinflammatory drugs. Inflamm Res 1995;44:1-0.

3. Tripathi KD. Essentials of Medical Pharmacology. $6^{\text {th }}$ ed. New Delhi: Jaypee Brothers Medical Publishers Ltd.; 2008

4. Jayashree V, Bagyalakshmi S, Devi KM, Daniel DR. In vitro antiinflammatory activity of 4-benzylpiperidine. Asian J Pharm Clin Res 2016;9:108-10.

5. Marnett LJ. The COXIB experience: A look in the rear view mirror. Annu Rev Pharmacol Toxicol 2009;49:265-90. 
6. Inotai A, Hanko B, Meszaro A. Trends in the non-steroidal antiinflammatorydrug market in six central-eastern European countries based on retail information. Pharm Epidemiol Drug Saf 2010;19:183-90.

7. Vonkeman HE, Van de Laar MA. Nonsteroidal anti-inflammatory drugs: Adverse effects and their prevention. Semin Arthritis Rheum 2010;39:294-312.

8. Garcia Rodriguez LA, Tacconelli S, Patrignani P. Role of dose potency in the prediction of risk of myocardial infarction associated with nonsteroidal anti-inflammatory drugs in the general population. J Am Coll Cardiol 2008;52:1628-36.

9. Subramanian V, Paramasivam V. Potential anti-inflammatory activity of Plumbago zeylanica. Asian J Pharm Clin Res 2017;10:372-5.

10. Reddy CM, Bhat VB, Kiranmai G, Reddy MN, Reddanna P, Madyastha KM. Selective inhibition of cyclooxygenase-2 by C-phycocyanin, a biliprotein from Spirulina platensis. Biochem Biophys Res Commun 2000;277:599-603.

11. Kuriakose GC, Kurup MG. Antioxidant and antihepatotoxic effect of Spirulina laxissima against carbon tetrachloride induced hepatotoxicity in rats. Food Func 2011;2:190-6.

12. Akao Y, Ebihara T, Masuda H, Saeki Y, Akazawa T, Hazeki $\mathrm{K}$, et al. Enhancement of antitumor natural killer cell activation by orally administered Spirulina extract in mice. Cancer Sci 2009;100:1494-501.

13. Mathew B, Sankaranarayanan R, Nair PP, Varghese C, Somanathan T, Amma BP, et al. Nutrition and Cancer: Evaluation of chemoprevention of oral cancer with Spirulina fusiformis 1995;24:197-202.

14. Karkos PD, Leong SC, Karkos CD, Sivaji N, Assimakopoulos DA. Spirulina in clinical practice: Evidence-based human applications. Evid Based Complement Altern Med 2011;2011:531053.

15. Sung-Ho OH, Ahn J, Kang DH, Lee HY. The effect of ultrasonificated extracts of spirulina maxima on the anticancer activity. Mar Biotechnol
2010;13:205-14

16. Skulberg OM, Carmichael WW, Codd GA, Skulberg R. Taxonomy of toxic Cyanophyceae (Cyanobacteria). In: Falconer IR, editor Algal Toxins in Seafood and Drinking Water. $1^{\text {st }}$ ed., Vol. 01. London, UK: Academic Press; 1993. p. 145-64.

17. Bhat VB, Madyastha KM. C-phycocyanin: A potent peroxyl radical scavenger in vivo and in vitro. Biochem Biophys Res Commun 2000;275:20-5.

18. Carvalho LR, Costa-Neves A, Conserva GA, Brunetti RL, Hentschke GS, Malone CF, et al. Biologically active compounds from cyanobacteria extracts: In vivo and in vitro aspects. Braz J Pharm 2013;23:471-80

19. Strunecky O, Bohunicka M, Johansen JR, Capkova K, Raabova L. Petr Dvorak Jiri Komárek. A revision of the genus Geitlerinema and a description of the genus Anagnostidinema gen. nov. (Oscillatoriophycidae, Cyanobacteria).Fottea 2017;17:114-26.

20. Hasler P, Dvořák P, Johansen JR, Kitner M, Ondřej V, Poulíčková A. Morphological and molecular study of epipelic filamentous genera Phormidium, Microcoleus and Geitlerinema (Oscillatoriales, Cyanophyta/Cyanobacteria). Fottea 2012;12:341-56.

21. Ejebe DE, Siminialayi IM, Emu dainowho JO, Ofesi U, Morka L. Analygesic and anti- inflammatory activities of the ethanol extract of the leaves of Helianthus Annus in Wister rats. Asian Pac J Trop Med 2013;3:341-7.

22. Azeem AK, Dilip C, Prasanth SS, Junise V, Shahima H. Antiinflammatory activity of the landular extracts of Thunnus alalunga. Asia Pac J Med 2010;3:412-20.

23. Lee SJ, Chinen J, Kavanaugh A. Immuno modulator therapy: Monoclonal antibodies, fusion proteins, cytokines and immunoglobulins. J Allergy Clin Immunol 2010;125:S314-S23. 